\title{
Studies on Sensory Analysis of Preparation of Date Palm Ready to Serve (RTS) Beverage by Using Whey and Soy Protein Powder
}

\author{
Nikhil Sharma $^{1 *}$, Sandeep G.M. Prasad ${ }^{1}$, Binod Kumar Bharti ${ }^{2}$, \\ Manisha Prasad ${ }^{3}$ and Nimish Kumar $\mathrm{Lal}^{4}$ \\ ${ }^{1}$ Warner College of Dairy Technology, SHUATS, Prayagraj (UP), India \\ ${ }^{2}$ SGIDT (Bihar Animal Sciences University) Patna (Bihar), India \\ ${ }^{3}$ Lucknow Christian College (UP), India \\ ${ }^{4}$ Department of agriculture, Mahaveer Institute of Technology, Meerut (UP), India \\ *Corresponding author
}

\section{Keywords}

Whey, Date palm, Soy protein, Colour and appearance,

Overall

acceptability

Article Info

Accepted:

12 July 2019

Available Online:

10 August 2019

\section{A B S T R A C T}

The present investigation is an attempt to formulate higher nutritional value of beverage with added health benefit by addition of date palm pulp and whey with soy protein. Studied for its sensory properties such as color and appearance, flavour and taste, consistency and overall acceptability by trained panelist by using 9 point hedonic scale. These experiments have four different treatment combinations such as $\mathrm{T}_{0}(93 \%$ whey with $7 \%$ sugar), $\mathrm{T}_{1}\left(70 \%\right.$ whey and $27 \%$ date palm pulp with $3 \%$ soy protein), $\mathrm{T}_{2}(60 \%$ whey and $37 \%$ date palm pulp with $3 \%$ soy protein), $\mathrm{T}_{3}(50 \%$ whey and $47 \%$ date palm pulp with $3 \%$ soy protein). The experiment $\mathrm{T}_{1}$ has been taken as $70 \%$ whey and $27 \%$ date palm pulp with $3 \%$ soy protein beverage for getting the best overall acceptability. It was found that among all treatments $T_{1}(7.82)$ scored higher in sensory evaluation and was considered as optimized product. The developed whey based ready to serve beverage from date palm could be recommended for the large scale production at industrial level.

\section{Introduction}

Phoenix dactylifera, commonly known as date or date palm is a flowering plant species in the palm family, Arecaceae, it cultivated for sweet fruit. Date is one of the oldest known fruit crops and has been cultivated in North Africa and the Middle East for at least 5000 years (Zohary and Hopf, 2000). Date trees is growing singly or forming a clump with several stems from a single root system.
Date fruits (dates) ranging from bright red to bright yellow in colour, depending on variety. They are very sweet containing about 75 percent of sugar when it dried. Date fruit are good sources of iron and potassium, calcium, chlorine, copper, magnesium and sulfur and a minor source of phosphorus. In addition, dates are a source of 16 amino acids and vitamins $\mathrm{A}, \mathrm{B}_{1}$, and $\mathrm{B}_{2}$ (Ahmed et al., 1995; Vandercook et al., 1980). Date fruit also have many medicinal uses. They can be used as an 
astringent for treating intestinal problems, treatment for sore throat and colds, relief of fever, cystitis, liver and abdominal problems. In India, the gum or exudate of dates is used for treating diarrhea and the roots are used to treat toothache (Barreveld, 1993; Dowson and Aten, 1962).

Whey is a valuable by-product obtained during coagulation of milk by using acid and/or rennet or physico-chemical process for the preparation of paneer, cheese, chhana, chakka and casein. By adding some ingredients in the whey, like sugar, colour and flavour to it, results in improvement of its taste, nutritive value and acceptability. So utilization of whey for the conversion into best beverage would be one of the important ways to utilize it. There is a lot of scope to explore whey of its utilization in beverage industries (Sakhale et al., 2012). Manufacture of beverages through lactic acid fermentation can provide desirable sensory profiles and it has already been considered an option to add value to whey (Salminen et al., 1991; Skudra et al., 1998; Pescuma et al., 2008).The main biological activities of whey proteins are cancer prevention, increase of glutathione levels, antimicrobial function and increase of satiety response (Valli and Trail, 2005; Madureira et al., 2007).Whey proteins provide highest quality absorption characteristics as well as sulfur contain essentially amino acids like leucine, iso leucine and valine which are important in growth and repair of tissue, improved muscle strength and body composition (Khare et al., 2007).

Soy protein is a protein that is isolated from soybean. Soy protein isolate has been used in foods for its functional properties. It is made from soybean meal that has been de-hulled and defatted. De-hulled and defatted soybeans are processed into three kinds of high protein commercial products such as soy flour, concentrates, and isolates. Recently, soy protein popularity has increased due to its use in health food products. It is generally regarded as being concentrated in protein bodies, which are estimated to contain at least $60-70 \%$ of the total soybean protein (William, 2008).

\section{Materials and Methods}

\section{Experimental site}

The experiment "Studies on sensory analysis of preparation of Date palm Ready to serve beverage by using whey and soy protein powder" was carried out in research lab, Warner College of Dairy Technology, Sam Higginbottom University of Agriculture Technology and Sciences, Prayagraj-211007, U.P. (India).

\section{Procurement and collection of ingredients}

Date palm purchased from local market of Prayagraj. Fresh paneer whey procured from Student Training Dairy (SHUATS). Soy protein purchased from local market of Prayagraj.

\section{Treatment combination}

$\mathrm{T}_{\mathbf{0}}$-Control prepared from whey and sugar (93:7)

$\mathrm{T}_{1}$-Experimental sample prepared from whey, date palm pulp and soy protein (70:27:3)

$\mathrm{T}_{2}$-Experimental sample prepared from whey, date palm pulp and soy protein (60:37:3) $\mathrm{T}_{3}$-Experimental sample prepared from whey, date palm pulp and soy protein(50:47:3)

Organoleptic quality: (9 Point hedonic scale) Sensory evaluation of Date palm Ready to serve beverage by using whey and soy protein powder

The sensory evaluation of Date palm Ready to serve beverage by using whey and soy protein powder samples was done by a panel of judge 
using a 9 point hedonic scale. Five experienced Technical staff members of the Warner college of Dairy Technology, Sam Higginbottom University of Agriculture, Technology and Sciences, Prayagraj served as a judging team and evaluated the samples of different treatment of Date palm Ready to serve beverage by using whey and soy protein powder. Numerical score was allocated for colour and appearances, flavour and taste, consistency and overall acceptability of Date RTS by using whey and soy protein. The numerical score was as an indication of the quality of Date RTS (Fig. 1 and 2; Table 1).

\section{Statistical analysis}

The data will be analyzed statically by Analysis of variance (ANOVA) at 5\% level of significance and Critical Difference (C.D) in WASP software and excel software.

\section{Results and Discussion}

The sensorial quality characteristics of Date palm Ready to serve beverage by using whey and soy protein powder play a vital role in attracting consumers to purchase the product. Consumer judges Date palm Ready to serve beverage by using whey and soy protein quality on the basis of its sensory parameters such as colour and appearance, flavour and taste, consistency and overall acceptability. Sensorial evaluation was done by using 9 point Hedonic scale.

Colour and appearance count of date palm ready to serve beverage by using whey and soy protein powder

From the above Table 2, colour and appearance score in samples of different treatments and control, the highest mean of colour and appearance score was recorded in the sample $T_{1}$ (7.88) followed by $T_{2}(7.24), T_{3}$ (6.74) and lowest score of control $\mathrm{T}_{0}(6.14)$. It indicates that higher the proportion of date palm pulp and soya protein, increase score of different treatments $T_{1}$ and $T_{2}$ has significant difference $(\mathrm{P}<0.5)$. The significant difference was further analyzed statistically to find out the C.D. between and within the different treatment combinations. The difference between the mean values of $\mathrm{T}_{0^{-}} \mathrm{T}_{1}(1.74), \mathrm{T}_{0^{-}}$ $\mathrm{T}_{2}$ (1.10), $\mathrm{T}_{0}-\mathrm{T}_{3}$ (0.60), $\mathrm{T}_{1}-\mathrm{T}_{2}$ (0.64), $\mathrm{T}_{1}$ $\mathrm{T}_{3}(1.14)$ and $\mathrm{T}_{1}-\mathrm{T}_{3}(1.14)$ greater than the C.D. value, 0.397 . Therefore, the difference was significant.

Flavour and taste score of Date palm Ready to serve (RTS) beverage by using whey and soy protein powder

From the above Table 3, The flavour and taste score in samples of different treatments and control, the highest mean flavor and taste score was recorded in the sample $\mathrm{T}_{1}(7.82)$ followed by $\mathrm{T}_{2}$ (7.06), $\mathrm{T}_{3}$ (6.84) and $\mathrm{T}_{0}(6.54)$.This indicates that, increased in proportion of date palmpulp and soya protein in the blend increased the score for flavour and taste of ready to eat beverage. There was significant differences $(\mathrm{P}<0.5)$ for consistency score between the mean values of between $\mathrm{T}_{0}$ and $\mathrm{T}_{3}$. The significant difference was further analyzed statistically to find out the C.D. between and within the different treatment combinations. The difference between the mean values of $\mathrm{T}_{0}-\mathrm{T}_{1}(1.28), \mathrm{T}_{0}-\mathrm{T}_{2}(0.52), \mathrm{T}_{0^{-}}$ $\mathrm{T}_{3}(0.3), \mathrm{T}_{1}-\mathrm{T}_{2}(0.76)$ and $\mathrm{T}_{1}-\mathrm{T}_{3}(0.98)$ greater than the C.D. value, 0.276 Therefore, the difference was significant. The difference between the mean values of $\mathrm{T}_{2}-\mathrm{T}_{3}(0.22)$ less than the C.D. value, 0.276. Therefore, the difference was non significant.

Consistency score of Date palm Ready to serve (RTS) beverage by using whey and soy protein

From the above Table 4, consistency score in samples of different treatments and control, 
the highest mean consistency score was recorded in the sample $T_{1}$ (7.9) followed by $\mathrm{T}_{2}$ (7.4), $\mathrm{T}_{3}(7.12)$ and $\mathrm{T}_{0}(7.06)$. It indicates that higher the proportion of date palm pulp and soya protein, increase score of consistency of different treatments has shown significant difference $(\mathrm{P}<0.5)$. The significant difference was further analyzed to find out the C.D. between and within the different treatment combinations. The difference between the mean values of $\mathrm{T}_{0^{-}} \mathrm{T}_{1}(0.84), \mathrm{T}_{0^{-}}$ $\mathrm{T}_{2}(0.34) \mathrm{T}_{1}-\mathrm{T}_{2}(0.50), \mathrm{T}_{1}-\mathrm{T}_{3}(0.78)$ and $\mathrm{T}_{2}-\mathrm{T}_{3}$ (0.28) greater than the C.D. value, 0.276 Therefore, the difference was significant and the difference between the mean values of $\mathrm{T}_{0^{-}}$ $\mathrm{T}_{3}$ (0.006) less than the C.D. value, 0.276. Therefore, the difference was non significant.

Table.1 Sensory parameters of control and experimental Date palm Ready to serve beverage by using whey and soy protein

\begin{tabular}{|l|c|c|c|c|}
\hline Treatment & $\begin{array}{c}\text { Colour and } \\
\text { appearance }\end{array}$ & $\begin{array}{c}\text { Flavour and } \\
\text { taste }\end{array}$ & Consistency & $\begin{array}{c}\text { Overall } \\
\text { acceptability }\end{array}$ \\
\hline $\mathbf{T}_{\mathbf{0}}$ & $6.14 \pm 0.41$ & $6.54 \pm 0.31$ & $7.06 \pm 0.11$ & $6.64 \pm 0.24$ \\
\hline $\mathbf{T}_{\mathbf{1}}$ & $7.88 \pm 0.19$ & $7.82 \pm 0.19$ & $7.90 \pm 0.15$ & $7.82 \pm 0.08$ \\
\hline $\mathbf{T}_{\mathbf{2}}$ & $7.24 \pm 0.20$ & $7.06 \pm 0.15$ & $7.40 \pm 0.30$ & $7.26 \pm 0.23$ \\
\hline $\mathbf{T}_{\mathbf{3}}$ & $6.74 \pm 0.31$ & $6.84 \pm 0.11$ & $7.12 \pm 0.19$ & $6.88 \pm 0.04$ \\
\hline C.D. at 5\% & 0.397 & 0.276 & 0.276 & 0.232 \\
\hline
\end{tabular}

Table indicates Mean \pm S.D. of different treatments

Table. 2 The data for colour and appearance count in sample of different treatment of Date palm Ready to serve beverage by using whey and soy protein powder are as following

\begin{tabular}{|l|c|c|c|c|}
\hline \multirow{2}{*}{ Replication } & \multicolumn{4}{|c|}{ Treatment } \\
\cline { 2 - 5 } & $\mathrm{T}_{0}$ & $\mathrm{~T}_{1}$ & $\mathrm{~T}_{2}$ & $\mathrm{~T}_{3}$ \\
\hline R1 & 5.6 & 7.6 & 7.0 & 6.9 \\
\hline R2 & 6.3 & 7.8 & 7.2 & 6.8 \\
\hline $\mathbf{R 3}$ & 6.2 & 8.0 & 7.4 & 6.2 \\
\hline R5 & 6.7 & 8.1 & 7.5 & 7.0 \\
\hline Mean & 5.9 & 7.9 & 7.1 & 6.8 \\
\hline Max & 6.14 & 7.88 & 7.24 & 6.74 \\
\hline Min & 6.7 & 8.1 & 7.5 & 7.0 \\
\hline C.D. at 5\% & 5.9 & 7.6 & 7.0 & 6.2 \\
\hline
\end{tabular}


Table.3 The data for flavour and taste score in sample of different treatment of date palm ready to serve beverage by using whey and soy protein are as following

\begin{tabular}{|l|c|c|c|c|}
\hline \multirow{2}{*}{ Replication } & \multicolumn{3}{|c|}{ Treatment } \\
\cline { 2 - 5 } & $\mathrm{T}_{0}$ & $\mathrm{~T}_{1}$ & $\mathrm{~T}_{2}$ & $\mathrm{~T}_{3}$ \\
\hline R1 & 6.9 & 7.9 & 7.2 & 6.8 \\
\hline R2 & 6.3 & 7.8 & 6.9 & 6.9 \\
\hline R3 & 6.5 & 8.0 & 7.1 & 7.0 \\
\hline R4 & 6.8 & 7.9 & 7.2 & 6.8 \\
\hline R5 & 6.2 & 7.5 & 6.9 & 6.7 \\
\hline Mean & 6.54 & 7.82 & 7.06 & 6.84 \\
\hline Max & 6.9 & 8.0 & 7.2 & 7.0 \\
\hline Min & 6.2 & 7.5 & 6.9 & 6.7 \\
\hline C.D. at 5\% & & \multicolumn{2}{|c|}{0.276} & \\
\hline
\end{tabular}

Table.4 The data for consistency score in sample of different treatment of Date palm Ready to serve (RTS) beverage by using whey and soy protein are as following

\begin{tabular}{|l|c|c|c|c|}
\hline \multirow{2}{*}{ Replication } & \multicolumn{4}{|c|}{ Treatment } \\
\cline { 2 - 5 } & T0 & T1 & T2 & T3 \\
\hline R1 & 7.0 & 8.0 & 7.5 & 7.0 \\
\hline R3 & 7.1 & 7.9 & 7.0 & 7.2 \\
\hline R4 & 6.9 & 8.1 & 7.2 & 7.4 \\
\hline R5 & 7.2 & 7.8 & 7.8 & 6.9 \\
\hline Mean & 7.1 & 7.7 & 7.5 & 7.1 \\
\hline Max & 7.06 & 7.9 & 7.4 & 7.12 \\
\hline Min & 7.2 & 8.9 & 7.8 & 7.4 \\
\hline C.D. at 5\% & 6.9 & 7.7 & 7.0 & 6.9 \\
\hline
\end{tabular}

Table.5 The data for overall acceptability score in sample of different treatment of Date palm Ready to serve (RTS) beverage by using whey and soy protein are as follows

\begin{tabular}{|l|c|c|c|c|}
\hline \multirow{2}{*}{ Replication } & \multicolumn{4}{|c|}{ Treatment } \\
\cline { 2 - 5 } & $\mathrm{T}_{0}$ & $\mathrm{~T}_{1}$ & $\mathrm{~T}_{2}$ & $\mathrm{~T}_{3}$ \\
\hline R1 & 6.5 & 7.8 & 7.2 & 6.9 \\
\hline R2 & 6.5 & 7.8 & 7 & 6.9 \\
\hline R3 & 6.9 & 7.9 & 7.5 & 6.9 \\
\hline R5 & 6.9 & 7.9 & 7.5 & 6.9 \\
\hline Mean & 6.4 & 7.7 & 7.1 & 6.8 \\
\hline Max & 6.64 & 7.82 & 7.26 & 6.88 \\
\hline Min & 6.9 & 7.9 & 7.5 & 6.9 \\
\hline C.D. at 5\% & 6.4 & 7.7 & 7 & 6.8 \\
\hline
\end{tabular}


Fig.1 Flow diagram for preparation of date palm ready to serve beverage by using whey and soy protein

Date palm pulp

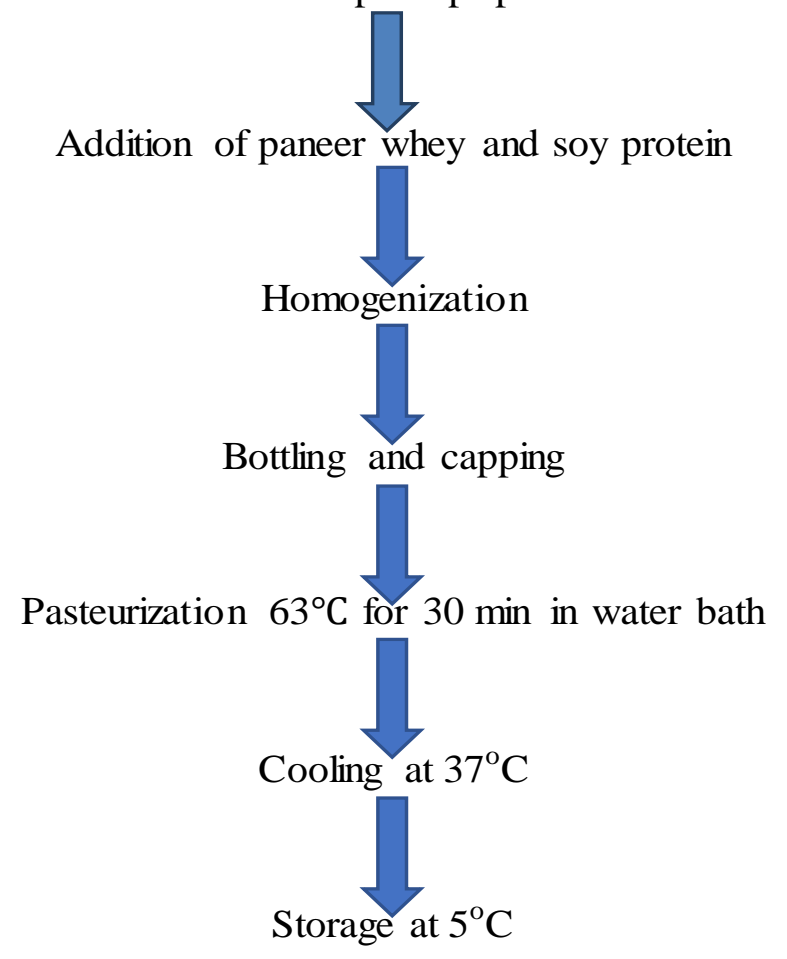

Fig.2 Graphical representation of sensory characteristics of mean value of date palm ready to serve (RTS) beverage by using whey and soy protein

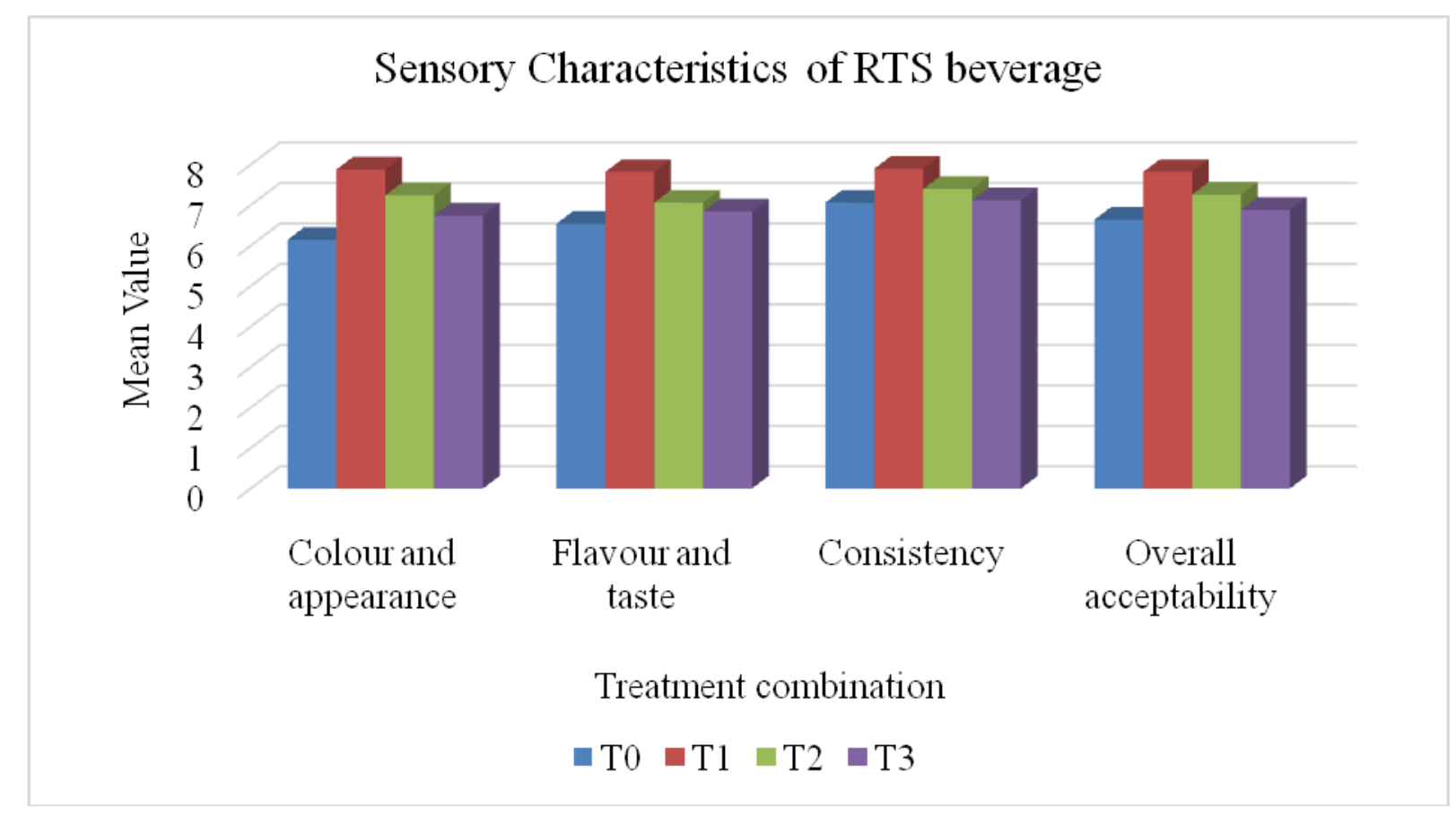


Overall acceptability score of date palm ready to serve (RTS) beverage by using whey and soy protein

From the above Table 5, overall acceptability score in samples of different treatments and control, the highest mean consistency percentage was recorded in the sample $\mathrm{T}_{1}$ (7.82) followed by $T_{2}$ (7.26), $T_{3}(6.88)$ and control $\mathrm{T}_{0}(6.64)$. It indicates that higher the proportion of date palm pulp and soya protein, increase score of different treatments $\mathrm{T}_{1}, \mathrm{~T}_{2}$ and $\mathrm{T}_{3}$ as compared to $\mathrm{T}_{0}$ has significant difference $(\mathrm{P}<0.5)$. The significant difference was further analyzed statistically to find out the C.D. between and within the different treatment combinations. The difference between the mean values of $\mathrm{T}_{0}-\mathrm{T}_{1}$ (1.18), $\quad \mathrm{T}_{0}-\mathrm{T}_{2} \quad(0.62), \quad \mathrm{T}_{0}-\mathrm{T}_{3} \quad(0.24), \quad \mathrm{T}_{1}-\mathrm{T}_{2}$ (0.56), $\mathrm{T}_{1}-\mathrm{T}_{3}(0.94)$ and $\mathrm{T}_{2}-\mathrm{T}_{3}(0.38)$ greater than the C.D. value, 0.232. Therefore, the difference was significant.

In conclusion, the study indicated that sensory score of Date palm Ready to serve (RTS) beverage by using whey and soy protein powder were increased significantly of different treatments to control. Colour and appearance score in samples of different treatments and control, the highest mean of colour and appearance score was recorded in the sample $T_{1}$ (7.88) and lowest score of control $\mathrm{T}_{0}(6.14)$. Similarly, The flavour and taste score in samples of different treatments and control, the highest mean flavor and taste score was recorded in the sample $\mathrm{T}_{1}$ (7.82) and lowest in sample $\mathrm{T}_{0}(6.54)$. Consistency score in samples of different treatments and control, the highest mean consistency score was recorded in the sample $T_{1}$ (7.9) and lowest score was found in sample $\mathrm{T}_{0}(7.06)$. It indicates that higher the proportion of date palm pulp and soya protein, increase score of consistency of different treatments has shown significant difference $\quad(\mathrm{P}<0.5)$. Overall acceptability score in samples of different treatments and control, the highest mean consistency percentage was recorded in the sample $T_{1}$ (7.82) and lowest was found in control $\mathrm{T}_{0}(6.64)$. It may be concluded that the Date palm Ready to serve (RTS) beverage by using whey and soy protein powder can be successfully prepared by using whey, date palm pulp and soya protein.

\section{Acknowledgement}

The authors are thankful to the Dean, Warner College of Dairy Technology, Sam Higginbottom University of Agriculture, Technology and Sciences, Prayagraj and Incharge Aggies Dairy for providing the facilities required for conducting the dissertation work.

\section{References}

Ahmed IA, Ahmed AWK and Robinson RK. Robinson. Chemical composition of date varieties as influenced by the stage of ripening. Food Chem. 1995; 54:305309.

Barreveld WH. Date palm products. Food and Agriculture Organization of the United Nations, Agricultural Services Bulletin no. 101, Food and Agriculture Organization of the United Nations, Rome, Italy. 1993.

Dowson VHW, A. Aten. Dates: Handling, processing, and packing. FAO Plant Production and Protection Series no. 13. Food and Agriculture Organization Agricultural Development, Food and Agriculture Organization, Rome, Italy.1962.

Khare A, Singh AP, Patil RS, Singh K, Singh AP. Utilization of whey into beveragesA Review. Beverage \& Food World. 2007; 34(5): 127-132.

Madureira AR, Pereira CI, Gomes AMP, Pintado ME, Malcata FX. Bovine whey proteins - Overview on their main 
biological properties. Food Research International. 2007; 40:1197-1211.

Pescuma M, Hébert EM, Mozzi F, Font de Valdez G. Whey fermentation by thermophilic lactic acid bacteria: Evolution of carbohydrates and protein content. Food Microbiology. 2008; 25:442-451

Sakhale BK, Pawar VN, Ranveer RC, Studies on the development and storage of whey based RTS beverage from mango cv. kesar, J. Food Proc. Technol., 2012; 3(3).

Salminen S, Gorbach S, Salminen K. Fermented whey drink and yogurt-type product manufactured using Lactobacillus strain. Food Technology. 1991; 45: 112.

Skudra L, Blija A, Sturmovica E, Dukalska E, Aboltins A, Karklina D. Studies on whey fermentation using lactic acid bacteria L. acidophilus and $L$. bulgaricus. Acta Biotechnology. 1998;
18: 277-288.

Valli C, Traill WB. Culture and food: A model of yogurt consumption in the EU. Food Quality and Preference. 2005; 16:291-304.

Vandercook CE, Hasegawa S, Maier P.Dates, In: S. Nagy and P.E. Shaw (eds.). Tropical and subtropical fruits: Composition, properties, and uses. AVI Publishing Company, Westport, CT.1980; 506-541

William Shurtleff, Akiko Aoyagi. History of Cooperative Soybean Processing in the United States: Extensively Annotated Bibliography and Sourcebook Soyinfo Center.2008.

Zohary D, and Hopf M. Domestication of plants in the old world: The origin and spread of cultivated plants in West Asia, Europe, and the Nile Valley. Oxford University Press, Oxon, UK.2000.

\section{How to cite this article:}

Nikhil Sharma, Sandeep G.M. Prasad, Binod Kumar Bharti, Manisha Prasad and Nimish Kumar Lal. 2019. Studies on Sensory Analysis of Preparation of Date Palm Ready to Serve (RTS) Beverage by Using Whey and Soy Protein Powder. Int.J.Curr.Microbiol.App.Sci. 8(08): 1652-1659. doi: https://doi.org/10.20546/ijcmas.2019.808.195 